\title{
Suitability of new subterranean clovers in the Canterbury region
}

\author{
KEITH WIDDUP and CHRIS PENNELL \\ AgResearch, PO Box 60, Lincoln \\ widdupk@agresearch.cri.nz
}

\begin{abstract}
The annual legume, subterranean clover, is adapted to permanent pastures in the summer drought-prone areas of eastern New Zealand. Dry summers over the last decade in Canterbury have renewed the interest from farmers in the use of sub clover. As the previously used cultivars Mt Barker and Tallarook are no longer available, a trial was established at AgResearch Templeton to evaluate a new series of cultivars and breeding lines from Australia together with recent New Zealand selections. The lines were sown in rows in May 1993 and assessed for seed set, autumn seedling regeneration and spring growth under sheep grazing for 4 years.

The new Australian cultivars had improved seed set and consistently better seedling regeneration and herbage yield compared with older cultivars. The late-flowering, small-leaved and densely branched types were best adapted to the Canterbury environment. The late-maturity cultivars Denmark and Leura, selected from Sardinian germplasm, re-established 50\% more seedlings and produced $25 \%$ greater late winter/ spring growth than Mt Barker and Tallarook in the third year. The New Zealand selection Ak 948 had similar performance to Denmark and Leura but the remaining selections were mediocre by the fourth year. The Sardinian ecotype breeding material appeared well-adapted to Canterbury conditions and future cultivars based on this material may be most suitable. Further trials are required in harsher sites to confirm these cultivar recommendations.
\end{abstract}

Keywords: Australian cultivars, dry regions, herbage yield, seedling regeneration, subterranean clover, Trifolium subterraneum

\section{Introduction}

Subterranean clover (Trifolium subterraneum) is a winter-active annual legume adapted to permanent pastures in the summer drought-prone areas of eastern New Zealand where it has a role in finishing lambs during late winter/spring. Sub clover was widely sown in these summer-dry regions in the 1940s, mainly with the Australian cultivars Mt Barker and Tallarook, but only spasmodically since (Suckling et al. 1983). Lack of new sowings, repeated droughts and poor grazing management has resulted in the current low proportions of sub clover in pastures and uneven distribution across regions.

Extensive evaluations of Australian-bred sub clover cultivars throughout summer-dry hill country regions in the late 1980s (Chapman et al. 1986; Sheath \& MacFarlane 1990; Williams et al. 1990) showed the unsuitability of early-flowering cultivars for New Zealand climatic and grazing conditions. Late-flowering types such as cv.Tallarook, which were prostrate and densely branched showed better reseeding, regeneration and herbage yields across most sites, although the midflowering cultivars Woogenellup and Nangeela were best adapted to the dry hill country of North Canterbury (Hoglund 1990). Tallarook has high oestrogen content that can pose fertility problems in breeding livestock and recent Australian programmes have aimed at selecting sub clovers with low formononetin levels. Tallarook and Mt Barker are now regarded as outclassed cultivars and are no longer available from Australia.

In recent years, a large pool of genetic material has been developed in Australian programmes and the late maturity group contains new material and recently bred cultivars of potential value to New Zealand conditions. Within New Zealand, a breeding programme using sub clover populations collected from the North Island hill country has identified a number of lines suitable for development of a cultivar adapted to summer-dry hill country (Dodd et al. 1995a). However, at this stage the New Zealand selections are not commercially available.

The objective of the study was to evaluate the most recent cultivars and breeding lines from Australia, to compare with the locally selected North Island material and provide information on the most suitable sub clover for use in summer-dry regions of the South Island.

\section{Material and methods}

\section{Genetic material}

The genetic material consisted of 15 Australian cultivars, 100 mid-late flowering lines from the 
Australasian Subterranean Clover and Alternative Legume Programme (ASCALIP), and five New Zealand selections developed at Whatawhata and Palmerston North (Table 1). Cultivars bred prior to 1980 were classed as old and those after 1980 as new. The 100 Australian breeding lines were divided into those developed from Australian germplasm (82), Mediterranean ecotypes (10) and Sardinian ecotypes (8). Sub clovers are categorised by flowering date, which is also indicative of the earliness or lateness of the spring peak in growth. The subspecies subterraneum are best adapted to free-draining loams and sands, subsp. yanninicum to winter waterlogged soils and subsp. brachycalycinum to alkaline soils.

The evaluation trial was situated at Templeton, Canterbury on a light Eyre soil with an Olsen P level of 12 and $\mathrm{pH}$ 5.8. In April 1993 the trial area was sprayed with glyphosate, cultivated and the sub clover lines drilled with a Hege91 precision seeder on 5 May 1993. All lines were inoculated with a recommended subterranean clover Rhizobium strain then $1 \mathrm{~g}$ of seed was drilled in a $2 \mathrm{~m}$ row with $1 \mathrm{~m}$ between rows. The trial was a randomised block design with five replications.

\section{Trial management}

Following establishment over autumn/winter 1993, the plots were rotationally grazed with sheep at monthly intervals in the spring. In 1994 and 1996, the trial was rotationally grazed in autumn/winter and set stocked in the spring. In March 1995, the trial was direct drilled with Kara cocksfoot to form a pasture sward. Plots were rotationally grazed in spring 1995 so that herbage DM assessments could be made from selected plots.

Seed set was assessed from eight, 5-cm-diameter cores taken from all plots across three reps in late January 1994 . The $\%$ hardseed was estimated from this sample as the ungerminated seed following incubation on moist filter paper at $20^{\circ} \mathrm{C}$. In 1994-1996, seedling regeneration was assessed during March/April using a visual score. Throughout the trial duration, vigour of the lines was visually scored prior to grazing with approximately five grazings/ year. Herbage DM yield was cut in late
Table 2 Seasonal rainfall (mm) from autumn 1993-summer 1996 and longterm mean seasonal rainfall at Lincoln.

\begin{tabular}{lccccc}
\hline & Autumn & Winter & Spring & Summer & Annual \\
\hline Rainfall 1993/94 & 190 & 65 & 195 & 190 & 640 \\
Rainfall 1994/95 & 146 & 177 & 98 & 82 & 503 \\
Rainfall 1995/96 & 89 & 234 & 154 & 63 & 540 \\
Rainfall 1996/97 & 160 & 215 & 85 & 170 & 630 \\
Long-term Rainfall & 190 & 173 & 147 & 170 & 680 \\
\hline
\end{tabular}


setting and seedling regeneration capacity of the lines in the third year.

\section{Flowering and plant type}

The Australian cultivars flowered over a 6-week period starting from 13 September with Dalkeith and ending on 26 October with Tallarook (Table 1). The pattern was similar to that recorded in Australia but 2-3 weeks later (Dear \& Scandral 1997). The mid-flowering cultivar Junee was bred as a replacement for the older Woogenellup, and the new mid-late flowering cultivars Goulburn, Denmark and Leura (all selected from Sardinian ecotype material) as replacements for $\mathrm{Mt}$ Barker and Tallarook. The New Zealand selections were all late-flowering, similar to Tallarook which has been promoted as the preferred ideotype for New Zealand conditions (Chapman et al. 1986; Dodd et al. 1995a).

The early- and mid-flowering cultivars were large leaved and open in plant type (Table 1). The older mid and late-flowering cultivars Mt Barker, Nangeela and Larisa were intermediate in plant type whereas the new cultivars Goulburn, Denmark and Leura were smallleaved and dense, closer in type to Tallarook and the New Zealand selections. Previous research has shown the importance of the dense, small-leaved habit for persistence under the grazing practices used in New Zealand (Chapman \& Williams 1990). At Whatawhata in the North Island, Dodd et al. (1995b) reported Denmark and Leura as larger leaved and more open compared with New Zealand selections. Possible reasons for the difference in plant habit of these cultivars in the Canterbury trial could be the expression of a more compact habit in a cooler environment and/or the lack of expression of the dense characteristic of New Zealand selections under the moderate grazing management in this trial. The Sardinian ecotypes were collected from areas where continuous grazing by sheep and goats was practised (P. Nichols, pers. comm.) and these types were consistently small-leaved and dense (Table 1).

\section{Seed set and seedling regeneration}

The ability to regenerate a new seedling population each year is critical to the success of sub clover. Most of the cultivars/lines produced moderate-high seed quantities in the first spring (Table 3). The new cultivars Junee, Goulburn, Karridale and Denmark, three of the New Zealand selections and the Sardinian ecotypes developed very high seed yields. The only exception amongst the new cultivars was Leura, which produced low seed yields together with most of the older cultivars including Mt Barker. All the lines showed low-moderate levels of hardseededness (Table 3 ) which suggested that re-establishment of the population every autumn was mostly dependent on seed set the previous spring.

Table 3 Seeds $/ \mathrm{m}^{2}, \%$ hardseed and seedling regeneration (relative to Mt Barker $=100$ ) of $T$. subterraneum lines/cultivars at Templeton, Canterbury.

\begin{tabular}{|c|c|c|c|c|c|}
\hline Line/selection & $\begin{array}{l}\text { Seeds } / \mathrm{m}^{2} \\
\text { Jan } 1994\end{array}$ & $\begin{array}{l}\% \text { Hardseed } \\
\text { Feb } 94\end{array}$ & $\begin{array}{l}\text { Regeneration } \\
\text { Apr } 1994\end{array}$ & $\begin{array}{l}\text { Regeneration } \\
\text { Mar } 1995\end{array}$ & $\begin{array}{c}\text { Regeneration } \\
\text { Mar } 1996\end{array}$ \\
\hline Breeding lines (82) & 9200 & 18 & 94 & 93 & 98 \\
\hline Mediterranean ecotypes(10) & 9900 & 19 & 85 & 99 & 101 \\
\hline Sardinian ecotypes (8) & 12400 & 18 & 98 & 111 & $147^{*}$ \\
\hline Whatawhata WS 536 & 10950 & 19 & 132 & 113 & 88 \\
\hline Whatawhata WS 1737 & 10300 & 19 & 105 & 78 & 69 \\
\hline Palmerston North Ak 920 & 12000 & 19 & 123 & 113 & 106 \\
\hline Palmerston North Ak 948 & 25400 & 21 & 115 & 126 & $144^{*}$ \\
\hline \multicolumn{6}{|l|}{ Australian cultivars } \\
\hline Dalkeith & 1800 & 10 & 55 & 74 & 31 \\
\hline Seaton Park & 6350 & 10 & 105 & 70 & 44 \\
\hline Trikkala & 10300 & 16 & 100 & 91 & 50 \\
\hline Gosse & 9700 & 31 & 82 & 87 & 63 \\
\hline Woogenellup & 4200 & 18 & 105 & 96 & 100 \\
\hline Clare & 1500 & 2 & 77 & 65 & 44 \\
\hline Mt Barker & 5100 & 20 & 100 & 100 & 100 \\
\hline Goulburn & 15300 & 17 & 95 & 78 & 94 \\
\hline Karridale & 13900 & 18 & 127 & 87 & 113 \\
\hline Nangeela & 9700 & 13 & 140 & 96 & 113 \\
\hline Denmark & 19300 & 27 & 118 & 126 & $156^{*}$ \\
\hline Larisa & 4300 & 12 & 86 & 104 & 50 \\
\hline Leura & 5000 & 6 & 68 & 91 & $169^{*}$ \\
\hline Tallarook & 9900 & 19 & 136 & 109 & 106 \\
\hline LSD(5\%) & 7200 & 16 & 31 & 42 & 62 \\
\hline
\end{tabular}

* Lines showing improvement over time 
Most lines regenerated high numbers of seedlings in April 1994, but over the next 2 years seedling regeneration of some cultivars/lines deteriorated compared with the standard Mt Barker (Table 3). In particular, the cultivars with earlier flowering and an open plant habit showed poorer seedling regeneration by the fourth year. These open types were more severely grazed by sheep reducing shoot density and therefore reducing the potential to flower and set seed, leading to a progressive decline of the sub clover population.

The late-flowering and small-leaved, dense cultivars Denmark and Leura, the Ak 948 selection and Sardinian ecotypes all showed improved seedling regeneration over time compared to Mt Barker (Table 3). Even though the 1994/95 season was dry, the late-flowering types showed the best regeneration capability over time. There was some contradiction with Leura showing poor seed set and seedling regeneration in 1994 but excellent regeneration in 1996. The low levels of hardseededness, together with a moist autumn in 1996, may explain the good seedling regeneration in Leura plots that year. However, in the long term, Leura may be vunerable in consistently dry environments.

The mid-flowering Junee (a replacement for Woogenellup) also showed improvement and may be useful in the sunny, northfacing hill country regions of Canterbury where the occurrence of early spring droughts would favour earlier seed set. Hoglund (1990) previously promoted the use of Woogenellup based on the performance at the dry North Canterbury Carvossa site.

\section{Herbage yield}

All the sub clover lines produced good spring growth in the establishment year except for the early flowering Dalkeith that did not capitalise on the longer growing season (Table 4). During 1994-1995, cultivar performance was highly correlated to flowering time $(\mathrm{r}=0.7 \mathrm{P}<0.001)$ with the late-flowering material producing the greatest growth and yield. However, in 1996 and 1997, the correlation was not significant ( $r=0.3$ ns) and growth was more variable. Factors such as seed set, ability to survive false strikes, shoot density, and seedling regeneration, all influenced the long-term persistence of the sub clovers.

Over the 4 years, the late-flowering cultivars Denmark, Leura and Nangeela (which is no longer commercially available) produced and maintained the greatest yields (Table 4). Even during the winter-early spring period when growth is important on dry Canterbury hill country, these three late-flowering cultivars continued to produce the greatest yields. The best non-cultivar lines were the Palmerston North selection Ak 948 and the Sardinian ecotypes. The poor performance of the Whatawhata selections relative to Australian material was surprising given the high regeneration ability and herbage yields in North Island trials (Dodd et al. 1995a). It is possible the Whatawhata selections are not well-adapted to the lower temperatures and rainfall of the South Island. In addition, the moderate grazing management in this trial allowed the Australian material to express its full potential. Further studies are required, particularly on dry hill country sites and with harder grazing management, as there are risks in making recommendations from one trial.

Table 4 Spring vigour scores (relative to Mt Barker $=100)$ and winter/spring herbage yield ( $k g D M /$ ha) of the T. subterraneum cultivars/lines evaluated in Canterbury from 1993-1997.

\begin{tabular}{lccccc}
\hline Line/selection & $\begin{array}{c}\text { Vigour } \\
\text { Nov 1993 }\end{array}$ & $\begin{array}{c}\text { Vigour } \\
\text { Nov 1994 }\end{array}$ & $\begin{array}{c}\text { kg DM/ha } \\
\text { Jun-Nov 95 }\end{array}$ & $\begin{array}{c}\text { Vigour } \\
\text { Sep 1996 }\end{array}$ & $\begin{array}{c}\text { Vigour } \\
\text { Sep 1997 }\end{array}$ \\
\hline Breeding lines (82) & 135 & 82 & 5410 & 85 & 75 \\
Mediterranean ecotypes(10) & 150 & 109 & 5630 & 70 & 60 \\
Sardinian ecotypes (8) & 170 & 120 & 6770 & 105 & 90 \\
Whatawhata WS 536 & 170 & 145 & 6050 & 65 & 65 \\
Whatawhata WS 1737 & 115 & 70 & 4860 & 45 & 25 \\
Whatawhata WS 1801 & 170 & 78 & 6060 & 80 & 80 \\
Palmerston North Ak 920 & 220 & 90 & 6810 & 85 & 70 \\
Palmerston North Ak 948 & 170 & 145 & 6920 & 130 & 135 \\
Australian cultivars & & & & & \\
Dalkeith & 60 & 33 & 2580 & 40 & 35 \\
Seaton Park & 130 & 55 & 4350 & 60 & 50 \\
Trikkala & 140 & 45 & 4885 & 85 & 80 \\
Gosse & 120 & 70 & 4950 & 75 & 65 \\
Junee & 150 & 100 & 5820 & 85 & 85 \\
Woogenellup & 100 & 90 & 5325 & 100 & 80 \\
Clare & 125 & 80 & 2930 & 35 & 35 \\
Mt Barker & 100 & 100 & 5950 & 100 & 100 \\
Goulburn & 170 & 80 & 6070 & 95 & 55 \\
Karridale & 170 & 120 & 6800 & 110 & 105 \\
Nangeela & 160 & 135 & 7660 & 120 & 120 \\
Denmark & 170 & 122 & 7370 & 130 & 100 \\
Larisa & 140 & 135 & 5485 & 70 & 35 \\
Leura & 200 & 165 & 7170 & 110 & 120 \\
Tallarook & 190 & 122 & 6700 & 80 & 100 \\
LSD(5\%) & 65 & 55 & 1950 & 33 & 45 \\
\hline
\end{tabular}

Currently, a cultivar bred for commercial use in New Zealand would require the seed industry to develop production capacity with new equipment and technology. Local useage of sub clover would need to increase substantially for a New Zealand cultivar to be 
economic to produce. The only practical choice available to farmers wanting to use sub clover is to sow Australiandeveloped cultivars. For the South Island, the new late-flowering cultivars appear to have some potential but in the North Island, these cultivars are not appropriate (Dodd et al. 1995a,b) although wider testing in the North Island East Coast is warranted.

\section{Conclusions}

1. The new Australian cultivars had improved seed set, seedling regeneration and herbage yield in the Canterbury environment compared to the older cultivars such as Mt Barker and Woogenellup.

2. The late-flowering types with small leaves, dense crowns and tolerance of moderate-high grazing pressure were best adapted. With the popular old cultivar Tallarook no longer available, Denmark and Leura are recommended. Further testing in drier sites is required to test the wider applicability of these new cultivars.

3. The new late-flowering Australian cultivars equalled or surpassed the performance of the North Island selections in the Canterbury trial.

4. Sardinian material appears to be adapted to the cool, dry Canterbury conditions and future Australian cultivars based on this germplasm are likely to be most suitable.

\section{ACKNOWLEDGEMENTS}

Thanks to Warren Williams of AgResearch for coordination and advice in the programme and Phil Nichols of the Western Australia Department of Agriculture for providing seed and information on the cultivars and breeding lines.

\section{REFERENCES}

Chapman, D.F.; Sheath, G.W.; MacFarlane, M.J.; Rumball, P.J.; Cooper, B.M.; Crouchley, G.;
Hoglund, J.H.; Widdup, K.H. 1986. Performance of subterranean and white clover varieties in dry hill country. Proceedings of the New Zealand Grassland Association 47: 53-62.

Chapman, D.F.; Williams, W.M. 1990. Evaluation of clovers in dry hill country. 8. Subterranean clover at "Ballantrae", New Zealand. New Zealand Journal of Agricultural Research 33: 569-576.

Dear, B.S.; Sandral, G.A. 1997. Subterranean clover in NSW - identification and use. In: AGFACTS, NSW Agriculture. Agfact P2.5.16.

Dodd, M.B.; Sheath, G.W.; Richardson, S. 1995a. Development of subterranean clover (Trifolium subterraneum L.) genotypes for New Zealand pastures. 1. Whatawhata persistence evaluation. New Zealand Journal of Agricultural Research 38: 3347.

Dodd, M.B.; Sheath, G.W.; Richardson, S. 1995b. Development of subterranean clover (Trifolium subterraneum L.) genotypes for New Zealand pastures. 3. Whatawhata production evaluation. New Zealand Journal of Agricultural Research 38: 5763.

Hoglund, J.H. 1990. Evaluation of clovers in dry hill country. 10. Subterranean clover in North Canterbury, New Zealand. New Zealand Journal of Agricultural Research 33: 585-590.

Sheath, G,W.; MacFarlane, M.J. 1990. Evaluation of clovers in dry hill country. 3. Regeneration and production of subterranean clover at Whatawhata, New Zealand. New Zealand Journal of Agricultural Research 33: 533-539.

Suckling, F.E.T.; Forde, M.B.; Williams, W.M. 1983. Naturalised subterranean clover in New Zealand. New Zealand Journal of Agricultural Research 26: 35-43.

Williams, W.M.; Sheath, G.W.; Chapman, D.F. 1990. Evaluation of clovers in dry hill country. 1. General objectives and description of sites and plant material. New Zealand Journal of Agricultural Research 32: 521-526. 
